\section{References}

1 Alleyne GAO, Hay RW, Picon DI, Stanfield JP, Whitehead RG. Proteinenergy malnutrition. Edward Arnold: London, 1976.

2 Coward WA, Lunn PG. The biochemistry and physiology of kwashiorkor and marasmus. Br Med Bull 1981 ;44:19-24.

3 Williams CD. A nutritional disease of children associated with a maize diet. Arch Dis Child 1933;8:423.

4 Williams CD. Kwashiorkor a nutritional disease of children associated with maize diet. Lancet 1935 ;ii:1151.

5 Trowell HC, Davies JN, Dean RFA. Kwashiorkor. London: Edward Arnold, 1954.

${ }^{6}$ Gopalan C. Kwashiorkor and marasmus: evolution and distinguishing features. In: McCance RA, Widdowson RM, eds. Calorie deficiencies and protein deficiencies. Edinburgh and London: Churchill Livingstone, 1968:49-58.

7 Tung HT, Wyatt RD, Thaxton P, Hamilton PB. Concentrations of serum proteins during aflatoxicosis. Toxicol Applied Pharmacol 1975;34:320-6.

${ }^{8}$ Hamilton PB. Inter-relationships of mycotoxins with nutrition. Federation Proceedings 1977;36:1899-1902.

${ }^{9}$ Richard JL. In: Rosenberg P, ed. Toxins: animal, plant and microbial Oxford: Pergamon, 1978:810.

10 Nwokolo C, Okonkwo P. Aflatoxin load of common food in savanna and forest regions of Nigeria. Trans $R$ Soc Trop Med Hyg 1978;72:329-32.

11 Goldblatt LA. Aflatoxin. New York: Academic Press Inc, 1969.

12 Waldman E. Seasonal variation in malnutrition in Africa. Trans $R$ Soc Med Hyg 1973;67:431.

13 Poskitt EM. Seasonal variation in infection and malnutrition at a rural paediatric clinic in Uganda. Trans $R$ Soc Trop Med Hyg 1972;66:931-6. 14 Dossetor J. The pattern of malnutrition in Zaria. $\mathcal{F}$ Trop Pediatr and Envir Child Health 1975;21:16-9.

15 Wellcome Trust Working Party, Lancet 1970:ii:302.

${ }_{16}$ Nelson DB, Kimbrough R, Landrigan DS, Hayes AW, Yang GC, Benanides J. Aflatoxin and Reye's Syndrome. A case control study. Pediatr 1980;60:865-9.

17 Horwitz W, ed. Official methods of analysis of the Association of Official Analytical Chemists. 12th ed. Washington, DC: AOFAC, 1975:7.

${ }^{18}$ Holaday CE, Lansden J. Rapid Screening method for aflatoxins in a number of products. F Agric Food Chem 1975;23:1134-6.

19 Linsell CA, Peers FC. Aflatoxin and liver cell cancer. Trans $R$ Soc Trop Med Hyg 1977;71:471-3.

${ }^{20}$ Amla I, Kamala CS, Gopalakrishna GS, Jayaraj AP, Sreenivasamurthy V, Parpia HAB. Cirrhosis in children from peanut meal contaminated by aflatoxin. Am $\mathcal{F}$ Clin Nutr $1971 ; 24: 609-14$.

${ }^{21}$ Krishnamachari KAVR, Ramesh V, Bhat VN, Tilak TBG. Investigations into an outbreak of hepatitis in parts of Western India. Indian 7 Med Res $1975 ; 63: 1036-49$.

22 Olson LC, Bourgeois CH, Cotton RB, Harikul S, Grossman RA, Smith TJ. Encephalopathy and fatty degeneration on the viscera in North eastern Thailand. Clinical syndrome and epidemiology. Pediatrics 1971; 47:707-16.

${ }^{23}$ Shank RC, Bourgeois CH, Keschamras N, Chandavimol P. Aflatoxins in autopsy specimens from Thai children with an acute disease of unknown aetiology. Food Cosmet Toxicol 1971;9:501-7.

(Accepted 16 August 1982)

\title{
Antenatal screening by measurement of symphysis-fundus height
}

\author{
JOHN P CALVERT, ERNEST E CREAN， ROBERT G NEWCOMBE，JAMES F PEARSON
}

\begin{abstract}
A study was undertaken to assess the value of symphysis-fundus measurement as a screening procedure for intrauterine growth retardation. The reproducibility of this measurement was investigated in two groups of six patients, each measured six times by six different observers. The intraobserver coefficient of variation was $4.6 \%$ and the interobserver coefficient of variation $6 \cdot 4 \%$. There was no evidence that experience aided consistency. A chart of symphysis-fundus measurements derived from Cardiff data was found to be similar to others previously published, and one measurement below the 10 th centile identified $64 \%$ of pregnancies in which the eventual birth weight was below the 10th centile for gestational age.

Symphysis-fundus measurement is a useful screening test; one chart could be used for any Caucasian population and should be incorporated into the maternity services "co-operation card."
\end{abstract}

\section{Introduction}

In 1953 Rumbolz and McGoogan ${ }^{1}$ showed the association between reduced growth of the uterine fundus and intrauterine

\footnotetext{
Departments of Obstetrics and Gynaecology and Medical Statistics, Welsh National School of Medicine, Heath Park, Cardiff CF4 4XN JOHN P CALVERT, MA, MRCOG, lecturer in obstetrics and gynaecology ERNEST E CREAN, MRCOG, registrar in general practice ROBERT G NEWCOMBE, PHD, FSS, lecturer in medical statistics JAMES F PEARSON, MD, FRCOG, reader in obstetrics and gynaecology
}

growth retardation. Beazley and Underhill in $1970^{2}$ showed wide patient variation in the height of the uterine fundus above the symphysis pubis (the symphysis-fundus height) and questioned the value of such measurements. The technique, although simple and inexpensive, has never been widely accepted, and uterine size continues to be recorded in various ways such as centimetres or "finger breadths" from the umbilicus or xiphisternum, or, simply, equivalent to $\mathrm{x}$ weeks.

In the last decade the difficulty of diagnosing intrauterine growth retardation on abdominal palpation has been recognised. Even experienced obstetricians detect fewer than $50 \%$ of cases, ${ }^{3-5}$ and the diagnostic value of current hospital antenatal care has been questioned. ${ }^{6}$ In an attempt to facilitate the diagnosis of intrauterine growth retardation several charts of the symphysis-fundus measurement have been made. ${ }^{7-10}$ Despite this the technique is still not popular, probably because of the lack of agreed principles (table I), the suggested need for an individual curve for each maternity unit, ${ }^{10}$ and the anticipated problem of observer variation.

To assess the magnitude of these problems we undertook the two-part study reported here. In the first part we assessed the reproducibility of symphysis-fundus measurements made by the same observer and by different observers, and in the second part

TABLE I-Different principles used in three charts of symphysis-fundus measurements

\begin{tabular}{|c|c|c|}
\hline Reference & Derivation of chart & Abnormal result \\
\hline Westin $^{8}$ & Mean birth weight \pm 1 SD & $\begin{array}{l}\text { One value }>2 \mathrm{~cm} \text { below mean or } \\
\text { three consecutive static or } \\
\text { declining values }\end{array}$ \\
\hline Belizan et $a l^{\circ}$ & $\begin{array}{l}\text { Birth weight between } \\
\text { 10th and } 90 \text { th centiles }\end{array}$ & One value $<10$ th centile \\
\hline Quaranta $e t a l^{10}$ & $\begin{array}{l}\text { Birth weight between } \\
25 \text { th and } 90 \text { th centiles }\end{array}$ & $\begin{array}{l}\text { Two consecutive or three isolated } \\
\text { values }<10 \text { th centile }\end{array}$ \\
\hline
\end{tabular}


we present a chart derived from Cardiff data and compare it with some of those previously published.

\section{Reproducibility}

We studied 12 patients at different stages of gestation in two groups of six. The symphysis-fundus height of each patient was measured by six observers in rotation until each observer had measured each of the six patients six times. The two groups of observers encompassed all grades of hospital staff, from a consultant who had been using symphysis-fundus measurements routinely for over a year to a medical student in the first week of his obstetric course.

All measurements were taken along the longitudinal axis of the uterus with the patient supine, her legs straight and her bladder empty. The measurements were made by lightly marking the position of the uterine fundus, then holding a piece of non-elastic string taut against the abdomen with a knot against the upper border of the symphysis pubis. The string was cut at the mark on the patient's skin, and this mark was then erased before the next observer made his measurement. The strings were labelled and subsequently measured to the nearest millimetre. All the strings from each session were measured by the same individual. Each patient was weighed and her height measured. Skinfold thickness was measured, using John Bull calipers (British Indicators Ltd), just below the inferior angle of the scapula, and the recorded measurc ment was the mean of two measurements taken vertically and two taken horizontally by the same observer.

\section{RESULTS}

Figure 1 shows the results for three patients. In case 1 there was little variation between observers (interobserver variation) compared
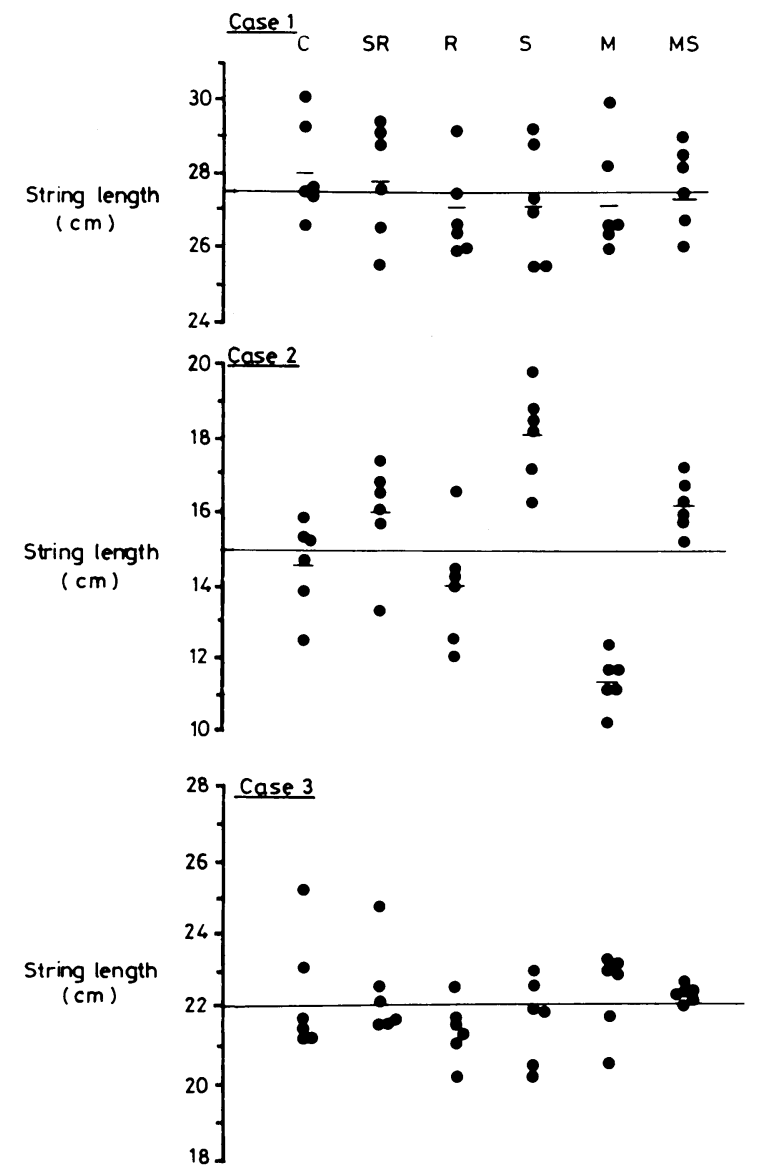

FIG 1-Examples of interobserver and intraobserver variation in measurements in three patients. Horizontal lines are overall mean measurements; horizontal bars are means for each observer.

$\mathrm{C}=$ Consultant. $\mathrm{SR}=$ Senior registrar. $\mathrm{R}=$ Registrar. $\mathrm{S}=$ Senior house officer. $M=$ Midwife. $M S=$ Medical student.

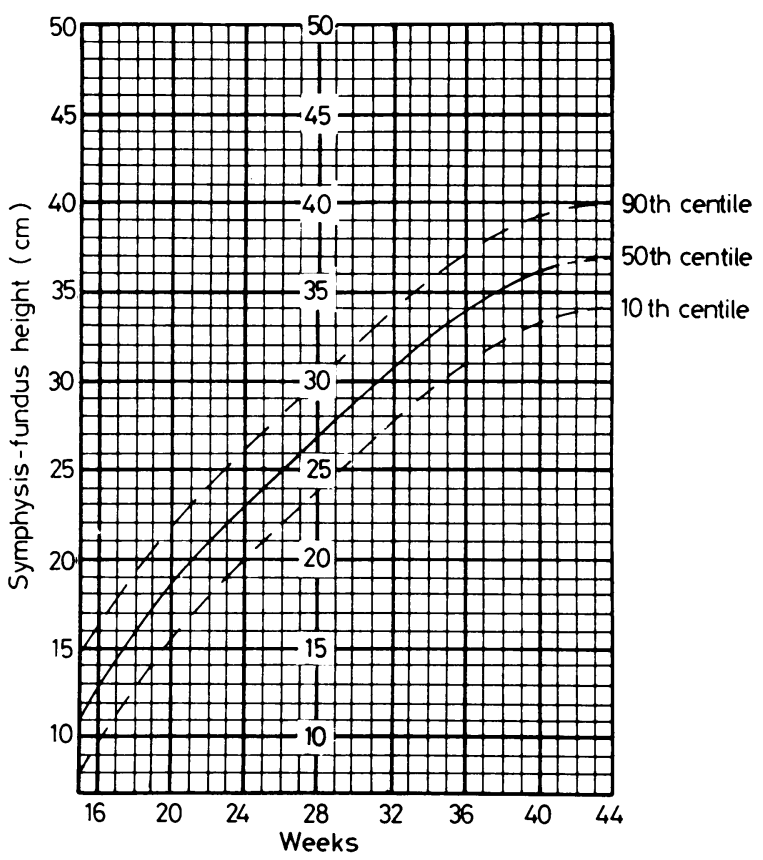

FIG 2-Chart of symphysis-fundus height based on Cardiff data.

with the variation in measurements by the same observer (intraobserver variation), but case 2 shows how different observers could form different assessments of the same patient. Experience did not reduce intraobserver variation: in case 3 the untrained student was the most consistent.

The pooled standard deviations of the measurements obtained by the two observers of each grade in both experimental sessions were: consultant $1.23 \mathrm{~cm}$, lecturer $1.34 \mathrm{~cm}$, registrar $1.35 \mathrm{~cm}$, senior house officer $1.13 \mathrm{~cm}$, midwife $1.20 \mathrm{~cm}$, and medical student 1.18 ; the overall standard deviation was $1.24 \mathrm{~cm}$. These results were not significantly different (Bartlett test: $\chi^{2}=2 \cdot 85, \mathrm{df}=5$ ). The average measurement for the whole series was $27.05 \mathrm{~cm}$, giving an intraobserver coefficient of variation of $4 \cdot 6 \%$. The pooled interobserver standard deviation was $1.72 \mathrm{~cm}$, giving an interobserver coefficient of variation of $6.4 \%$.

Comparison of interobserver and intraobserver standard deviations in the 12 subjects showed no correlation (Spearman rank correlation coefficient $+0 \cdot 224)$; similarly, there was no correlation between either interobserver or intraobserver standard deviation for each patient and her mean symphysis-fundus height, skinfold thickness, or weight corrected for height.

\section{The normal curve}

PATIENTS AND METHODS

The symphysis-fundus height was measured as part of the routine antenatal examinations of all patients under the care of one of us (JFP). The measurements were made as described above, except that the distance between the mark on the fundus and the upper border of the symphysis pubis was measured direct with a tape measure held taut on the patient's skin. After delivery birthweight centiles were calculated from tables. ${ }^{11}$

RESULTS

Data were available from 381 pregnancies in non-diabetic mothers with sure dates, confirmed by clinical examination and often ultrasonography, within the first 16 weeks. Twenty-five patients delivered babies weighing on or below the 5th centile $(6.6 \%)$ and 20 babies were between the 5 th and 10 th centiles $(5 \cdot 2 \%)$. Only 23 babies had a birth weight above the 90 th centile.

Figure 2 shows the normal curve derived from 1775 observations on the 313 patients for whom the birth weight was between the 10th and 90 th centiles. To avoid possible bias because a different subset of the pregnancies yielded data at each week of gestation, adjusted weekly 
means were obtained using the multiple classification option in the analysis of variance program of the Statistical Package for the Social Sciences. ${ }^{12}$ These values were then smoothed by the use of a threeweek moving average. The standard deviations of measurements at each week of gestation varied between $1.72 \mathrm{~cm}$ and $3.61 \mathrm{~cm}$ with no consistent trend and were pooled to give the value of $2.42 \mathrm{~cm}$ used to calculate the centile norms, assuming a normal distribution.

\section{COMPARISON WITH OTHER CHARTS}

Table II compares examples from the Cardiff data with the charts of Westin, ${ }^{8}$ Belizan et al, ${ }^{9}$ and Quaranta et al. ${ }^{10}$ The Cardiff chart and the charts of Westin and Belizan et al were all derived from pregnancies in which the birth weights were distributed symmetrically about the mean, and their mean values were very similar. The chart of Quaranta et al was derived from an asymmetrical population (table I) and had, as expected, slightly higher values. The Cardiff chart and the chart of Belizan et al were the only two to be derived from pregnancies in which the birth weight was between the 10th and 90 th centiles for gestation, and the centile lines for measurements at each week of gestation were also similar. The centile lines for the chart of Quaranta et al were slightly higher, as expected, but suggested approximately the same scatter of measurements at each week of gestation, even though the chart was derived from pregnancies with a narrower range of birth weights.

\section{DIAGNOSTIC VALUE}

Because the charts of Belizan et al, Quaranta et al, and Westin were derived and used in different ways, direct comparisons of their results with ours would be meaningless. We therefore tested the ability of our chart to detect those pregnancies with varying degrees of growth retardation using a variety of previously suggested criteria. ${ }^{8-10}$ Table III shows the results.

\section{Discussion}

The intraobserver and interobserver coefficients of variation of $4.6 \%$ and $6.4 \%$ show that measurements of the symphysis- fundus height are not precise. In practice neither end point is easy to identify, and fetal movements change the apparent fundal height. The Cardiff chart was derived only from pregnancies in which the birth weight was between the 10th and 90th centiles, to ensure that it reflected only normal pregnancies, and the differences between this chart and others derived in the same way were much less than the observer variation. This suggests that one chart could be used for any Caucasian population.

Perhaps more pertinent was the finding that, when measurements were made in a manner that avoided the effects of memory, anticipated result, or terminal digit preference, experience did not aid consistency. The implication of this is that the technique may be used by medical and paramedical staff without loss of accuracy, which would not only free senior medical staff to fulfill other functions but also be of particular value in underdeveloped societies. Similarly, neither the gestational age nor the patient's physique affected the accuracy of measurement.

The choice of the lower limit of normal values of symphysisfundus height is arbitrary and allows the sensitivity of the test to be varied, depending on acceptable levels of false-positive results and the facilities for more detailed investigation of positive results. In our series one measurement of symphysisfundus height below the 10th centile $(3.1 \mathrm{~cm}$ below the mean) selected out $100(26 \%)$ patients as having growth-retarded babies, and at delivery this group contained $29(64 \%)$ of the babies weighing below the 10th centile, with a false-positive rate of $71 \%$. We found no evidence that pregnancies with static or declining symphysis-fundus heights ${ }^{8}$ were likely to suffer intrauterine growth retardation, although they might be at risk in some other way.

We believe that measurement of the symphysis-fundus height provides a communicable way of expressing fundal height and an easy and inexpensive screening test for intrauterine growth retardation. As no special skill is necessary it may be used with equal accuracy by all who care for pregnant women. A chart of symphysis-fundus heights would be a useful addition to the standard "co-operation card" and would enhance communication between midwife, general practitioner, and hospital obstetrician.

TABLE II-Comparison of values obtained from chart of symphysis-fundus height based on Cardiff data with values obtained from three other charts

\begin{tabular}{|c|c|c|c|c|c|c|c|c|c|c|}
\hline \multirow{2}{*}{$\begin{array}{c}\text { Gestational } \\
\text { age } \\
\text { (weeks) }\end{array}$} & \multicolumn{4}{|c|}{ Mean } & \multicolumn{3}{|c|}{ 10th centile } & \multicolumn{3}{|c|}{ 90th centile } \\
\hline & Cardiff & Westin $^{8 *}$ & $\underset{\text { et } a l^{\mathbf{9}}}{\text { Belizan }}$ & $\begin{array}{l}\text { Quaranta } \\
\text { et } a l^{10 *}\end{array}$ & Cardiff & $\begin{array}{c}\text { Belizan } \\
\text { et } \text { al }^{\circ}\end{array}$ & $\begin{array}{l}\text { Quaranta } \\
\text { et } a l^{10 *}\end{array}$ & Cardiff & $\begin{array}{c}\text { Belizan } \\
\text { et } a l^{\circ}\end{array}$ & $\begin{array}{l}\text { Quaranta } \\
\text { et } a l^{10 *}\end{array}$ \\
\hline $\begin{array}{l}16 \\
20 \\
24 \\
28 \\
32 \\
36 \\
40\end{array}$ & $\begin{array}{l}12.8 \\
18.8 \\
22.9 \\
26 \cdot 8 \\
30 \cdot 2 \\
33 \cdot 7 \\
36.2\end{array}$ & $\begin{array}{l}18.0 \\
22.0 \\
26.0 \\
29 \cdot 6 \\
33.0 \\
35.5\end{array}$ & $\begin{array}{l}18.5 \\
22.5 \\
26.5 \\
30.5 \\
33.5 \\
34.5\end{array}$ & $\begin{array}{l}20 \cdot 2 \\
24 \cdot 1 \\
28 \cdot 1 \\
31 \cdot 8 \\
34 \cdot 7 \\
36 \cdot 3\end{array}$ & $\begin{array}{r}9 \cdot 7 \\
15 \cdot 7 \\
19 \cdot 8 \\
23.7 \\
27 \cdot 1 \\
30 \cdot 6 \\
33 \cdot 1\end{array}$ & $\begin{array}{l}16.0 \\
20.0 \\
23.5 \\
27.3 \\
30.5 \\
32.0\end{array}$ & $\begin{array}{l}16 \cdot 7 \\
21 \cdot 0 \\
25 \cdot 1 \\
28 \cdot 7 \\
31 \cdot 6 \\
33 \cdot 6\end{array}$ & $\begin{array}{l}15.9 \\
21.9 \\
26.0 \\
29.9 \\
33.3 \\
36.8 \\
39.3\end{array}$ & $\begin{array}{l}23.0 \\
25.3 \\
29.3 \\
33.3 \\
36.8 \\
38.5\end{array}$ & $\begin{array}{l}23 \cdot 8 \\
27 \cdot 4 \\
31 \cdot 2 \\
34 \cdot 8 \\
38 \cdot 0 \\
39 \cdot 7\end{array}$ \\
\hline
\end{tabular}

*From published graph.

TABLE III-Results obtained from Cardiff chart when different criteria indicating growth retardation were applied

\begin{tabular}{|c|c|c|c|c|c|c|c|}
\hline \multirow{3}{*}{$\begin{array}{l}\text { Criteria used to indicate } \\
\text { growth retardation }\end{array}$} & \multicolumn{3}{|c|}{ Results } & \multicolumn{4}{|c|}{ Predictive performance } \\
\hline & \multirow{2}{*}{ Birth weight } & \multicolumn{2}{|c|}{ No predicted as: } & \multirow{2}{*}{ Birth weight } & \multirow{2}{*}{ Sensitivity* } & \multirow{2}{*}{ Specificity $†$} & \multirow{2}{*}{$\begin{array}{c}\text { False-positive } \\
\text { rate }\end{array}$} \\
\hline & & Retarded & Not retarded & & & & \\
\hline $\begin{array}{l}\text { One value }>2 \mathrm{~cm} \text { below mean, or } \\
\text { three consecutive static or } \\
\text { declining values (Westin }{ }^{*} \text { ) }\end{array}$ & $\begin{array}{l}<5 \text { th centile }(n=25) \\
5 \text { th-10th centile }(n=20) \\
>10 \text { th centile }(n=336) \\
\text { All patients }\end{array}$ & $\begin{array}{l}18 \\
16 \\
133 \\
167(44 \%)\end{array}$ & $\begin{array}{l}7 \\
4 \\
203 \\
214(56 \%)\end{array}$ & $\begin{array}{l}<5 \text { th centile } \\
<10 \text { th centile }\end{array}$ & $\begin{array}{l}72 \% \\
76 \%\end{array}$ & $\begin{array}{l}58 \% \\
60 \%\end{array}$ & $\begin{array}{l}89 \% \\
80 \%\end{array}$ \\
\hline $\begin{array}{l}\text { One value }<10 \text { th centile } \\
\quad\left(\text { Belizan } \text { et } a l^{\circ}\right)\end{array}$ & $\begin{array}{l}<5 \text { th centile } \\
5 \text { th-10th centile } \\
>10 \text { th centile } \\
\text { All patients }\end{array}$ & $\begin{array}{l}15 \\
14 \\
71 \\
100(26 \%)\end{array}$ & $\begin{array}{r}10 \\
6 \\
265 \\
281(74 \%)\end{array}$ & $\begin{array}{l}<5 \text { th centile } \\
<10 \text { th centile }\end{array}$ & $\begin{array}{l}60 \% \\
64 \%\end{array}$ & $\begin{array}{l}76 \% \\
79 \%\end{array}$ & $\begin{array}{l}85 \% \\
71 \%\end{array}$ \\
\hline $\begin{array}{l}\text { Two consecutive or three isolated } \\
\text { values <10th centile } \\
\text { (Quaranta } \text { et }^{\prime l^{10}} \text { ) }\end{array}$ & $\begin{array}{l}<5 \text { th centile } \\
5 \text { th-10th centile } \\
>10 \text { th centile } \\
\text { All patients }\end{array}$ & $\begin{array}{l}9 \\
7 \\
21 \\
37(10 \%)\end{array}$ & $\begin{array}{l}16 \\
13 \\
315 \\
344(90 \%)\end{array}$ & $\begin{array}{l}<5 \text { th centile } \\
<10 \text { th centile }\end{array}$ & $\begin{array}{l}36 \% \\
36 \%\end{array}$ & $\begin{array}{l}92 \% \\
\mathbf{9 4} \%\end{array}$ & $\begin{array}{l}76 \% \\
57 \%\end{array}$ \\
\hline
\end{tabular}

* Sensitivity = Proportion of low birthweight babies predicted as being retarded

+ Specificity $=$ Proportion of appropriately grown (or large) babies predicted as being not retarded. 
Supplies of the Cardiff symphysis-fundus chart may be obtained from Titan Press Ltd, Wroughton Place, Fairwater, Cardiff (tel: 0222-569321).

Requests for reprints should be sent to Dr J P Calvert, lecturer in obstetrics and gynaecology, Welsh National School of Medicine, Heath Park, Cardiff CF4 4XN.

\section{References}

' Rumbolz WL, McGoogan LS. Placental insufficiency and the small undernourished full-term infant. Obstet Gynecol 1953;1:294-301.

${ }^{2}$ Beazley JM, Underhill RA. Fallacy of the fundal height. Br Med $\mathcal{F} 1970$; iv : 404-6.

${ }^{3}$ Campbell S. Fetal growth. In: Beard RW, Nathanielsz PW, eds. Fetal physiology and medicine. London: W B Saunders, 1976:278.

4 Tejani N, Mann LI, Weiss RR. Antenatal diagnosis and management of the small-for-gestational-age fetus. Obstet Gynecol 1976;47:31-6.

${ }^{5}$ Rosenberg K, Grant JM, Hepburn M. Antenatal detection of growth retardation: actual practice in a large maternity hospital. $\mathrm{Br} \mathcal{F}$ Obstet Gynaecol 1982;89:12-5.

${ }^{6}$ Hall MH, Chng PK, MacGillivray I. Is routine antenatal care worth while? Lancet $1980 ; \mathrm{ii}: 78-80$.

' Effer SB. Perinatal intensive care: obstetrical considerations. In: Goodwin JW, Godden JO, Chance GW, eds. Perinatal medicine. Baltimore: Williams and Wilkins, 1976:578-92.

${ }^{8}$ Westin B. Gravidogram and fetal growth. Acta Obstet Gynecol Scand $1977 ; 56: 273-82$.

${ }^{9}$ Belizan JM, Villar J, Nardin JC, Malamud J, de Vicuna LS. Diagnosis of intra-uterine growth retardation by a simple clinical method: measurement of uterine height. Am $\mathcal{F}$ Obstet Gynecol 1978;131:643-6.

${ }^{10}$ Quaranta P, Currell R, Redman CJ, Robinson JS. Prediction of small-fordates infants by measurement of the symphysial-fundal-height. $\mathrm{Br} \mathcal{F}$ Obstet Gynaecol $1981 ; 88: 115-9$.

11 Thomson AM, Billewicz WZ, Hytten FE. The assessment of fetal growth. Fournal of Obstetrics and Gynaecology of the British Commonwealth 1968; 75:903-16.

${ }_{12} \mathrm{Nie} \mathrm{NH}$, Hull CH, Jenkins JG, Steinbrenner K, Bent DH. Statistical package for the social sciences. 2nd ed. New York: McGraw Hill, 1975.

(Accepted 22 fuly 1982)

\section{SHORT REPORTS}

\section{Terbutaline aerosol given through pear spacer in acute severe asthma}

Pressurised aerosols are an ineffective way of giving bronchodilators in acute severe asthma. Less than $10 \%$ of a correctly administered dose from a standard pressurised aerosol reaches the bronchial tree, ${ }^{1}$ and this may be reduced in acute severe asthma. Even under normal circumstances not more than $75 \%$ of patients are able to use pressurised aerosols efficiently. ${ }^{2}$ Those who are unable to co-ordinate aerosol actuation with inhalation obtain benefit from the addition of an extension tube or spacer to the mouthpiece of the aerosol. ${ }^{3}$ The pear spacer (Nebuhaler) is a plastic tube $(750 \mathrm{ml}$ volume) with a oneway valve that obviates the need for co-ordination. It is designed to contain the shape of the aerosol cloud when it leaves the actuator and increase the availability of the drug for inhalation. Newman et $a l^{4}$ showed that the deposition of radio aerosol in the whole lung is improved from $7 \cdot 8 \%$ to $11.5 \%$ with a tube spacer and to $13 \%$ with a pear spacer. ${ }^{4}$

We used a pear spacer to deliver an aerosol bronchodilator (terbutaline) to patients with acute severe asthma and compared it with an electric nebuliser.

\section{Patients, methods, and results}

We studied 18 patients ( 11 women, seven men; age 15-67 years). All gave informed consent and satisfied the following: pulse rate $110 / \mathrm{min}$ or greater; forced expiratory volume in one second $25 \%$ predicted or less; arterial oxygen pressure $9.3 \mathrm{kPa}(70 \mathrm{~mm} \mathrm{Hg})$ or less; and forced expiratory volume in one second and forced vital capacity (best of three) measured on admission and 10 minutes later not varying by more than $10 \%$. Patients who had received treatment with a bronchodilator within the previous two hours were excluded. Intravenous hydrocortisone $200 \mathrm{mg}$ was given at the start of the study and oxygen administered throughout.

Patients were randomly allocated into two groups: one group received terbutaline $4 \mathrm{mg}$ via an electric nebuliser (RTU 4; Medic Aid Ltd) followed after 30 and 60 minutes by two doses of terbutaline $2 \mathrm{mg}$ (eight puffs) via a Nebuhaler; the second group received terbutaline $4 \mathrm{mg}$ (16 puffs) via a Nebuhaler followed by two doses of $2 \mathrm{mg}$ via a nebuliser 30 and 60 minutes later.

Forced expiratory volume in one second, forced vital capacity (Vitalograph dry spirometer), pulse, and blood pressure were measured on admission and 10 minutes later immediately before the first administration. Forced expiratory volume in one second, forced vital capacity, and pulse were recorded immediately after each administration and at 10-minute intervals until a plateau was reached. The blood pressure was recorded after 30 minutes and at the end of the study. The figure shows the mean baseline values after each administration of terbutaline.

The data were subjected to analysis of variance. Each treatment produced a significant rise in forced expiratory volume in one second and forced vital capacity $(p<0.01)$, but there was no significant difference between the two modes of administration. Pulse rate and blood pressure tended to fall throughout the study, and no adverse side effects were noted despite a total of $8 \mathrm{mg}$ inhaled terbutaline being given.

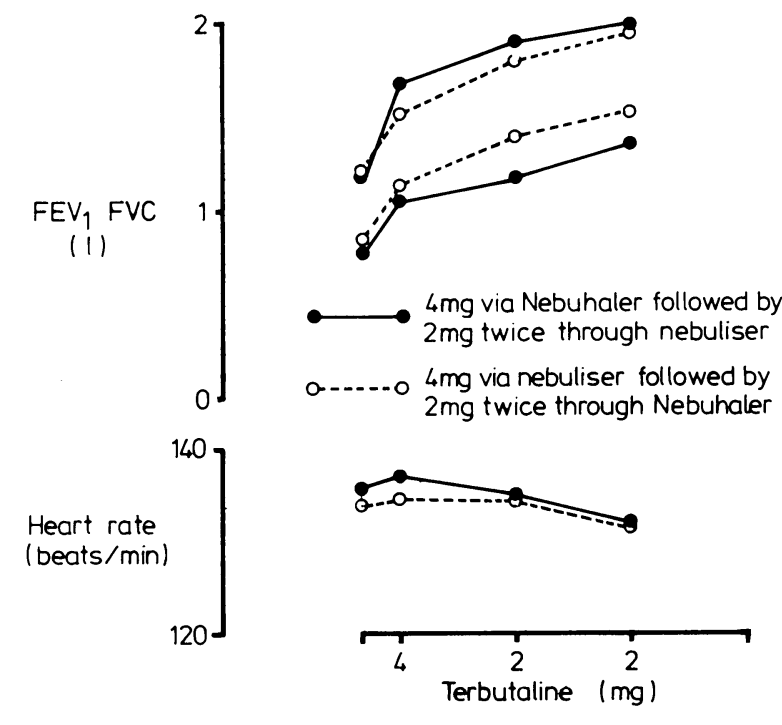

Mean baseline values and mean maximum values of heart rate, forced expiratory volume in one second $\left(\mathrm{FEV}_{1}\right)$, and forced vital capacity (FVC) after each administration of terbutaline.

\section{Comment}

In severe asthma a bronchodilator given by any route may produce a fall in arterial oxygen partial pressure. Oxygen should be given before, during, and after its administration, as it was in this study.

Nebulised terbutaline produces just as effective bronchodilation as the intravenous drug in acute severe asthma. ${ }^{5}$ In our patients terbutaline administered via a conventional pressurised aerosol with a Nebuhaler attached was as effective as wet nebulisation of the drug. The Nebuhaler requires no power supply and is smaller, less complicated, easier to assemble, and vastly less expensive than a nebuliser. We recommend its use in the treatment of acute severe asthma both in the home and in hospital.

1 Davies DS. Pharmacokinetics of inhaled substances. Postgrad Med $\mathcal{f}$ 1975; 51,suppl 7:69-75.

${ }^{2}$ Earis JE, Bernstein A. Misuse of pressurised nebulisers. Br Med $\mathcal{F}$ 1978; $\mathrm{i}: 1554$. 